Id en line Revista de Psicologia. Ano 2, No. 4, Fevereiro de 2008 - ISSN 1981-1179.

\title{
Opinião
}

\section{EDUCAR É TRANSFORMAR}

Manuel José Pina Fernandes (1)

Esta fórmula simples deveria ser usada na sua mais exata tradução. Transformar é dar nova forma a alguma coisa ou pessoa, o que implica, logo numa primeira abordagem, contrariar um percurso. Mas com esta sentença cria-se uma polêmica que, de alguma forma, nos obriga a refrescar a memória sobre quais foram, nos últimos anos, os pressupostos filosóficos do modelo educativo por aqui praticado atualmente.

O primeiro desses princípios e o mais nocivo é o princípio rousseauniano da criança boa, ou boazinha, ou pretensamente boazinha. Deste princípio decorre a idéia largamente difundida de que a escola tem de ser um local divertido e os professores uns amigões desses seres em formação.

O segundo princípio é o da absoluta igualdade entre todas as crianças, assim como entre todos os seres sociais. Segundo ele, a todos devem ser dadas, igualmente, as mesmas oportunidades. Só que, infelizmente, isso não significa que todos, de modo unificado, as aproveitem da mesma maneira. Ao não se estabelecerem diferenças, opta-se por um nivelamento que pode ser inferior, medíocre, em vez de dar a mão aos mais problemáticos sem tolher os mais capacitados. A escola trata como iguais, os desiguais.

Ao longo dos últimos anos tem-se satanizado valores como o da autoridade, do rigor, da exigência e da disciplina. O esforço e o mérito de cada um, fatores que diferenciam os mais capazes dos menos capazes, foram transformados em uma ameaça à pureza dos dogmas da bondade natural e da igualdade. Por este princípio devemos abominar as classificações, as diferenças. O resultado que sobressai dessa prática está visível. 
Id en line Revista de Psicologia. Ano 2, No. 4, Fevereiro de 2008 - ISSN 1981-1179.

Em nome destes princípios, o modelo educativo, foi objeto de sucessivas tentativas experimentais e reduzido à mais elementar expressão: uma educação sem memória, com métodos simplificados, todo o esforço estudantil foi removido, o excesso de especialização roubando qualquer perspectiva de conjunto e valores foram fragmentados sem referência a qualquer pano de fundo. O simples exercício do pensar sistemático, do raciocínio, do treinamento do cérebro como única forma de fortalecê-lo, tudo isso parece supérfluo: aborrece os alunos, acentua as diferenças. Não se pode revelar o potencial e o esforço de uns e o desinteresse ou incapacidade de outros, o mérito e o demérito ficam ofuscados por um nivelamento que não frutifica.

Apenas exemplificando, imaginemos como se sairia, hoje, um aluno de dez anos de idade, se fosse submetido a provas idênticas às que enfrentamos, noutros tempos, nos exames de admissão às Escolas Técnicas e aos Liceus. Decerto não as superaria. E não as superaria por ser menos inteligente? Não. Por não ter sido capacitado para tal. Basta olhar os resultados das diversas provas que são aplicadas no plano nacional, como o SAEB.

O objetivo da escola deixou de ser o de educar e ensinar. A escola tornou-se um depósito de todos os problemas, desde aqueles meramente burocráticos até aos eminentemente sociais. Sob a égide de um emaranhado legislativo, com instalações precárias, com péssimos profissionais que ela mesma forma e a falta de verba orçamentária, soterram-se as condições de dignidade social: aumenta a fragilidade das redes familiares, enfrenta-se a solidão, revelam-se comportamentos abusivos, fomenta-se a pré-delinquência, cresce o abandono.

Não se reflete se, com estas práticas, estamos a produzir analfabetos funcionais, iletrados ou se muitos dos alunos apenas fazem da escola um simples local de passagem obrigatória. O mais importante, politicamente falando, é saber se as estatísticas e os indicadores são favoráveis à elite dominante. Para cumprir estas idiossincrasias impõe-se que todas as crianças estejam matriculadas numa escola. Não há uma preocupação maior em garantir a essas crianças a permanência e a qualidade de ensino/aprendizagem. Basta que a freqüentem, mesmo se pouco e mal e sejam pífios os resultados obtidos.

Há quem queira comparar o ensino privado com o ensino público, mas fazer essa comparação, hoje, é comparar o incomparável. O ensino público formou gerações e gerações com excelente qualidade. Não há como afirmar que apenas o ensino privado vem 
Id en line Revista de Psicologia. Ano 2, No. 4, Fevereiro de 2008 - ISSN 1981-1179.

apresentando resultados positivos. Eu frequentei um ensino público, mas, atualmente, as circunstâncias específicas das escolas públicas, abertas à massificação, não lhe permitem selecionar os seus alunos, como acontece no privado. As escolas públicas se desgastam muito mais para resolver problemas na direção da correnteza ou em sentido contrário, não têm autonomia financeira e refletem, na sua agonia, todas as ameaças do seu envolvimento social.

Não há como deixar de reconhecer estes sintomas. Não se pode negar que, com tais atitudes, se está perdendo muito da humanização que gostaríamos de ver na sociedade atual quando oferecemos à população uma cultura minimalista, aligeirada e permissiva, que aliena as crianças e os jovens. Mudar tal situação é quase um ato revolucionário, é preceito ontológico e do domínio da filosofia dos princípios. Não podemos culpar apenas o sistema. Necessário se faz que cada educador, pela sua reflexão, perceba a educação como um fato sociológico do mais elevado nível e dê seu contributo para a transformação. Falo, certamente, de um lugar comum, de um problema nacional do qual as culpas devem ser partilhadas. De um problema que será de difícil solução se não se pensar uma política formativa em que o principal alvo seja o ser humano e não a satisfação do capital.

(1) Manuel José Pina Fernandes é Mestre em Educação e Professor da Universidade Regional do Cariri - URCA, Crato-CE. E-mail: profmanuelfernandes@gmail.com. 